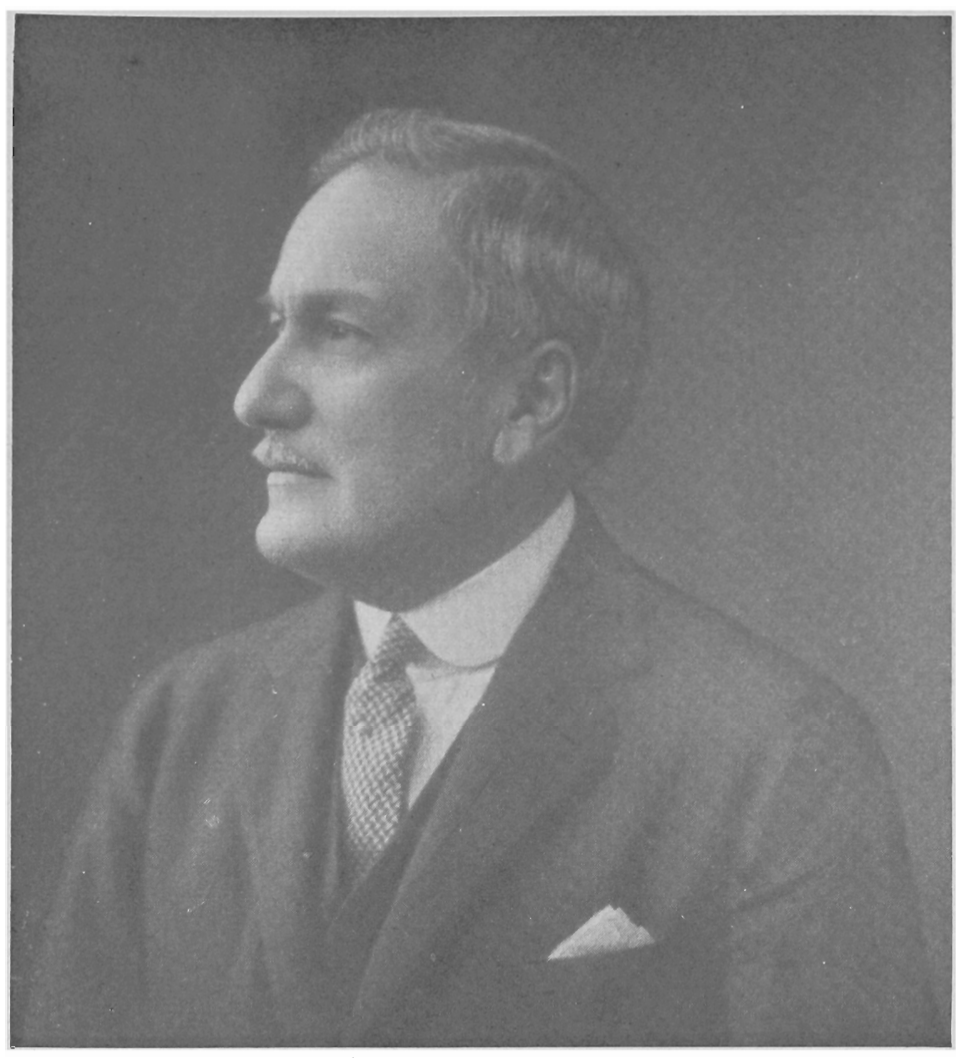

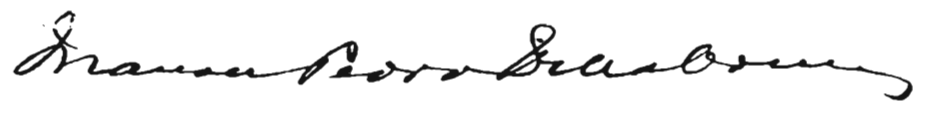




\title{
Prof. Dr. Manoel Pedro Villaboim
}

\author{
Fallecido a 11 de setembro e se- \\ pultado a 12, no Cemiterio da Con- \\ solação.
}

Raphael Sampaio

Nasceu no Estado da Bahia, municipio de Cachoeira, a 16 de julho de 1867, do legitimo consorcio do Conselheiro Manoel Pedro Alvares Moreira Villaboim, juiz do Tribunal da Relação da antiga Ciôrte, e de D. Umbelina de Oliveira Passos Villaboim.

Concluindo os preparatorios, muito moço, matriculouse na Faculdade de Direito de Recife, recebendo o gráo de bacharel em sciencias juridicas e sociaes a 3 de dezembro de 1885 .

Logo após a formatura foi nomeado Promotor Publico da Capital da antiga provincia, hoje Estado do Espirito Santo. Ahi occupou, em brilhante ascensão, os cargos de Juiz Municipal e Juiz de Direito.

Como magistrado demonstrou a sua já solida cultura juridica e a rectilinea da sua consciencia.

Por portaria do Presidente da Republica foi nomeado Lente Substituto da 5. ${ }^{\text {a }}$ Secção, da Faculdade de Direito de S. Paulo, em 2 de maio de 1891, tomando posse em 9 de junho do mesmo anno. Nessa data recebeu o gráo de doutor em Sciencias Juridicas e Sociaes.

Tendo fallecido o dr. José Rubino de Oliveira, Lente Cathedratico de Direito Administrativo, o professor Manoel Pedro Villaboim submetteu-se a concurso, produzindo pro- 
vas brilhantes, especialmente a monographia sobre o Contencioso Administrativo.

Em consequencia desse concurso, foi nomeado, por decreto do Governo da Republica, em 23 de dezembro de 1892 , Lente Cathedratico da 1. ${ }^{\mathrm{a}}$ cadeira da Terceira Serie do Curso de Sciencias Sociaes, tomando posse e entrando em exercicio, a 31 de dezembro de 1892.

Em 7 de fevereiro de 1896 foi, por decreto do Governo Federal, designado para a cadeira de Sciencia da Administração e Direito Administrativo, designação que tomára essa disciplina em virtude da reforma do ensino que voltava a unificar os cursos juridicos, abolindo o curso de Notariado, criação, tambem, da reforma Benjamin Constant.

Nessa disciplina foi jubilado por decreto Federal de 13 de junho de 1932, a pedido, e nos termos do artigo 64 do Decreto n.० 19.851 de 11 de abril de 1931.

0 que foi o mestre durante quasi meio seculo de ensino na Faculdade de Direito, attestam os seus discipulos e os seus collegas, considerando-o provecto professor, juiz sensivel e justo, companheiro que afinava os seus affectos pela delicadeza e pela cordura.

Advogado, militou no fôro de S. Paulo, e conquistou os florões da mais alta jerarchia como insuperavel na dialectica, na defeza das causas que patrocinava, e, sobretudo, na elevação e elegancia com que terçava as suas armas com os adversarios.

Era respeitado e querido, pela sua rectidão impeccavel, e, porque nunca fez de um adversario forense ou politico, um inimigo pessoal.

Durante duas legislaturas representou o povo paulista na Camara Estadoal, tendo feito parte em 1911 da Commissão de Revisão Constitucional.

Em 1915 foi eleito deputado federal. Fez parte das Commissões de Diplomacia e Tratados, Justiça e Finanças. 
Em 1927 era escolhido leader da sua bancada e da maioria da Camara. Deixou esse encargo, quando foi eleito senador em 1930.

Parlamentar de fino quilate, occupou-se de preferencia da defeza do café; da inconstitucionalidade de impostos federaes sobre a renda e sobre o transito de mercadorias; da inconstitucionalidade dos Tribunaes Regionaes; dos casos de accidentes no Trabalho; da fixação das Horas de Trabalho e outras providencias tendentes a amparar a situação dos operarios; do regimen de Portos e outros.

O professor Manoel Pedro Villaboim fez parte em 1923 da Côrte Permanente de Arbitragem de Haya, honra a que bem poucos juristas de renome universal alcançaram.

Foi um grande jurista, um eminente professor, um excelso advogado, exemplarissimo chefe de familia, virtuoso cidadão e affectuoso amigo.

E', pois, um patrimonio legitimo desta Faculdade, e o seu nome será sempre lembrado com profunda admiração e immensa saudade. 